\title{
A COMPREHENSIVE FRAMEWORK OF DESIGN THINKING APPROACH IN KNOWLEDGE MANAGEMENT: A REVIEW IN ACADEMIC CONTEXT
}

\author{
SK MAMUN MOSTOFA \\ Department of Information Science and Library Management, \\ University of Dhaka \\ Nilkhet Rd, Dhaka 1000, Bangladesh \\ E-mail address: mostofa@du.ac.bd \\ ORCID: https://orcid.org/0000-0001-9125-6754 \\ ROSLINA OTHMAN \\ Department of Library and Information Science, KICT, \\ International Islamic University \\ Jalan Gombak, 53100 Kuala Lumpur, Malaysia \\ E-mail address: roslina@iium.edu.my \\ ORCID: https://orcid.org/0000-0001-7674-141X

\section{DEBARSHI MUKHERJEE} \\ Department of Business Management, \\ Tripura University (Central University) \\ 8H Tripura University gate, Agartala, Tripura 799022, India \\ E-mail address: debarshimukherjee@tripurauniv.in \\ ORCID: https://orcid.org/0000-0001-9039-0329

\section{KHANDAKAR KAMRUL HASAN} \\ Department of Business Management, \\ Tripura University (Central University) \\ 8H Tripura University gate, Agartala, Tripura 799022, India \\ E-mail address: kkhasan@gmail.com \\ ORCID: https://orcid.org/0000-0002-2462-1165
}

\section{ABSTRACT}

Aim. Design thinking (DT) is an essential context for knowledge management $(\mathrm{KM})$, as it promotes the link between KM initiatives and an organisation's strategic 
goals and objectives. This article analyses the DT process in terms of its capability to create KM. The detailed analysis focuses on the aspect of the DT's working mechanism, namely how KM is represented and created in the process. This article examines the DT procedure in terms of its ability to generate design knowledge. In this regard, the main purpose of this paper is to review the approaches to KM applied to DT and to suggest directions in which such a supervisory system could evolve.

Methods. This study is thematic in its nature, and it was prepared on the basis of secondary data, an inclusive review of the literature, and, similarly, the computation of secondary information. To formulate this paper, the researchers referred to research books, earlier published articles, conference papers, and numerous research reports.

Results and conclusions. This article concludes by proposing an intuitive model for DT and KM for its successful application in higher learning institutions in the areas of course design institutional strategy formation and faculty resource sharing.

Originality. There are very few papers published in the aspects of KM in DT perspective. This study is one of the leading papers aiming to discover realistic support for the DT approach in KM.

Key words: Knowledge Management, design thinking, design knowledge, knowledge sharing, educational institutions, design systems

\section{INTRODUCTION}

$\mathrm{T}$ his paper reviews the Knowledge Management (KM) frameworks applied to Design Thinking (DT) and provides guidance for how such a system of oversight could evolve. Overall view of the KM evolving while following a DT strategy helps to retain a clear picture of what is being done and why it is being done. It is important to develop holistic methodologies and processes which emphasize the DT and the cultural aspects of KM. The authors believe that it is important to provide a system that is both perspective and concise to achieve a KM system that satisfies all the requirements and is compatible with DT. Bringing KM in line with DT would establish a supervisory structure, by specifying what DT is, which determines a more coherent interpretation of a KM system. The purpose of this paper is to identify and explain the theoretical framework for advanced research on difficulties and prospects of effect of KM on DT. KM is a discipline of study for supporting a level amalgamation of inventive demands that have ensued from the present-day commercial and technical contexts, into advanced learning institutions.

\section{What is DT?}

Tracing the origin of DT development is challenging and various researchers on their design research typically provide different analyses of the history of DT (Kimbell \& Street, 2009). Various literature on design research, management, and organisational studies usually provide diverse interpretations of the ancestry of DT. However, in the late 1960s, DT was introduced and embedded in the earlier stage of design methodologists to sketch differences between the design science and the natural sciences (Alexander, 1964; Gregory, 1966; Simon, 1969; as cited in Elsbach, 2018). DT is a particular 
tool for solving impressive difficulties (Buchanan, 1992; Rittel, 1972) and for fostering creative solutions based on human-centred approach of multidisciplinary teams. DT is also referred to as human-centred because the public and its interests are at the epicentre of this strategy and many KM systems are already human-centred. It is an imaginative tricky solving method that has been used in the management and design fields (Johansson-Sköldberg, 2013, as cited in Leuzinger, 2013). DT is a human-centred problem-solving method that might be applied in higher educational institutions to improve the expertise of the 21st century and enrich imagination and revolution (Luka, 2014). For impending decision-making problems, DT is a demanding form of knowledge about the design process (Simon, 1996; as cited in Wang \& Wang, 2008). In present times the idea of DT has been considered predominantly by administrators everywhere in the world (Hassi \& Laakso, 2011). DT promotes discovery strategy and aesthetic meaning-making due to the presence of interdisciplinary scenarios and collaborative inquiries (Zahedi, Poldma, Baha, \& Haats, 2012).

\section{What is KM?}

KM plays a significant role in any institution by promoting the acquisition, storage, development, and distribution of information to achieve organisational objectives (Agarwal, Poo, \& Goh, 2005). On the other hand, KM which was initiated in the early 1990s in the private sector (Feather, 2003), meaning that it is a new area for which an organised, widely known framework has not yet been established (Beckman, 1998). KM is the practice of enabling individuals, teams and whole societies to mutually and consistently develop, exchange and apply information in order to attain their goals in a better way (Young, 2008; as cited in Mostofa \& Sultana, 2019). KM is fundamentally about people - how they develop, exchange and use information, so KM programmes should include both dimensions of gathering and communicating. The gathering dimension involves linking people to knowledge and it is related to capturing and disseminating specific information. The communicating dimension involves linking people to people - specifically people who know - and thus improves the flow of tacit knowledge through superior human interaction and communication progressions. Trends include an alignment of tacit knowledge and explicit knowledge coded through technology (Walch, Morita, Karagiannis, \& Yamaguchi, 2019). KM is an emerging arena and many organisations are actively participating in KM in order to leverage information both internally and externally to stockholders and employers (Rubenstein-Montano, 2001).

The rest of the paper is structured as follows: first, the objectives and goals of this investigation; then, in the second section, the methodology applied in this study; in the third section, a thorough analysis of the subject literature from different published and unpublished sources, in the fourth and final section, the proposed theoretical model, which followed by conclusions and suggestions for future work. 


\section{AIMS AND OBJECTIVES OF THE STUDY}

The main aim of this paper is to review the KM methods proposed in the DT and recommended ways for how such a supervisory system could evolve. The objectives of the study are:

- to explain the influence of DT approach on KM,

- to propose a model developing and applying DT to KM approach.

\section{METHODOLOGY}

This study is thematic in its nature and it was prepared on the basis of secondary data, inclusive review of the literature, and similar computation of secondary information. To formulate this paper the researchers referred to books, earlier published articles, conference papers, and numerous research reports. This paper is the result of meticulous literature search, not only of published materials but also of all unpublished sources, reports and documents which are available. For this study, we considered seventeen KM and DT models which provide theoretical frameworks, such as Max Boisot (1987), Thomas H. Davenport and Laurence Prusak (1998), Rodney McAdam and Sandra McCreedy (1999), Hsiangchu Lai and Tsai-Hsin Chu (2000), Peter Tyndale (2000), Michael Stankosky and Carolyn R. Baldanza (2001), Maryam Alavi and Dorothy E. Leidner (2001), Ganehs D. Bhatt (2001), Mihir Parikh (2001), Jennifer Rowley (2001), Simone C. Stumpf and Janet T. McDonnell (2002), France Bouthillier and Kathleen Shearer (2002), Randy Frid (2003), Varintorn Supyuenyong and Nazrul Islam (2006), Sara L. Beckman and Michael Barry, (2007), Louay Karadsheh et al. (2009) and David A. Kolb (2014). These studies suggested the likeness and changes between the different KM and DT models.

\section{LITERATURE REVIEW}

This section discusses the literature relating to DT and KM. The study of the literature is structured in two main themes which are given below.

\section{Why is DT required in educational institutions?}

In current technologically advanced times a person needs to develop different sets of skills to achieve success in life and DT is one of these skills (Shute \& Becker, 2010). Rim Razzouk and Valerie Shute (2012) stated that DT skills help to solve difficult problems as well as respond to unexpected changes; furthermore, the design requires in-depth cognitive processes, which potentially help students develop their acute intellectual skills. Shouhong Wang and Hai Wang (2008) found that students have positive learning experiences and overall satisfaction while studying within the DT approach. They stated that students like to have the induction model for KM related projects to develop DT. They explained that an experimental module guided by the induction model 
is beneficial for students to progress DT for KM. M. Ann Welsh and Gordon E. Dehler (2012) indicated that DT produces a circumstance for teamwork which allows learners to attain attributes consistent with integrative novices, serious reflection, the ability to negotiate distinctiveness, be involved in creative analysis, become trained in knowledge conversion, and create tangible and implementable results. DT has an influential impact on enhancing individual and institutional learning. Educational institutions established cognitive perceptions leading towards intelligent communities who understand problems and propose solutions (Chujfi \& Meinel, 2020).

\section{Why is KM needed in educational institutions?}

Elizabeth Lank (1997) elucidated that there are several benefits of KM that can be expected, for instance, workers will expend less time for information and expertise. C. Jackson Grayson and Carla O'Dell (1998) stated that KM may assist various organisations in being more competitive by using innovative knowledge to shrink costs, upsurge speed, and meet customer requirements. Furthermore, Priti Jain (2013) distinguished that KM is a mechanism for developing, obtaining, exchanging and disseminating knowledge that serves to assist the higher education institution and its society by providing the right information at the right time to take the right decision to realise the organisational goals. In another study, Anita Cucovic and Osman Cucovic (2014) found that knowledge and efficient organisational KM encourage the creativity of the employees, which is realised through different innovations. KM is an essential element of the information economy and is the focus of artificial intelligence technology. Knowledge elicitation facilitated at educational institutions offers an effective way of managing brainstorming sessions and innovative ideas along with consensus-building exercises (Dorton, Tupper, \& Maryeski, 2017). An operational KM policy leads to the creation of knowledge which is capable of being transmuted and absorbs the market assessment of the inventive merchandise, service area and business process.

\section{FRAMEWORKS REVIEWS}

\section{Analysis of DT in KM}

In KM framework, there is no universal description of what constitutes DT approach and several definitions are common to several frameworks; however, the ordering or structure of the system differs. In its descriptive structures, there is a lack of consensus about what should be used while studying KM in DT system. Michael J. Marquardt (1996) suggests first the acquisition of knowledge and then the creation of knowledge; Jay Liebowitz (1999) includes both finding and acquisition of knowledge in its framework, but there is an additional up-front requirement for the transformation of DT into KM. Performance at most levels of KM requires understanding people's needs and motivations. Inherently, designing solutions to those needs would make their information 
work simpler and then more efficient as it is important to them. This can be challenging because what people sometimes say they want may not be what they need.

KM projects would be much more effective if the interests of information workers were recognised as part of the design process and taken into account. But the determination to continue to advocate for improvement in actions needs to be grounded in a deep understanding of the individuals involved. It takes a lot more in-depth research and interaction with the technology practitioners and clients that we are trying to support, but it helps to build better solutions for our knowledge staff and to potentially impact on the growth in a greater manner. The main part of this article introduces our proposed theoretical model in which we map different types of KM to the process steps of DT. Finally, we analyse and interpret the suggested model and the resulting implications on DT in KM and discuss possible contributions to DT education and practice, as well as limitations and future work.

\section{DT logical frameworks}

A vital challenge for managing efficiently any human-centred difficulty in a DT setting is the transition, reception and incorporation of information through the participants. The problem is especially severe when information is interpreted pragmatically. The authors argue that the DT attempts at understanding the mentality of administrators or collective capacity builders seeking to find solutions to the wicked issues shown in the table.

Table 1

DT teachniques and applications

\begin{tabular}{ccc}
\hline Design Techniques & Design Application & Mode of Contribution \\
\hline Synchronous System & $\begin{array}{c}\text { Seminar Room } \\
\text { Conversation }\end{array}$ & $\begin{array}{c}\text { Similar Phase } \\
\text { Similar Habitation }\end{array}$ \\
\hline Asynchronous & Bulletin Board System (BBS) & Different Time \\
Technique & Notice Board and agent-based & Same Place \\
\hline Distributed & Video Conferencing & Same Time \\
Synchronous & Tele-conferencing and & Different Place \\
Collaboration (DSC) & discussion & \\
\hline Dispersed & Email & Diverse Time \\
Asynchronous & Short Messaging System(SMS) & Altered Residence \\
Cooperation & Voice Mail and Fax Machine & \\
& Agent-Based & \\
\hline
\end{tabular}

Source: Abdullah, Selamat, Sahibudin, \& Alias, 2000.

\section{KM and DT logical frameworks}

In cooperation with DT, KM can disseminate information in four ways, depending on whether the mode of communication is synchronous or asynchronous, or both. The technique for dissemination of knowledge used by DT is shown in the table. 
Table 2

Knowledge Dissemination Technique

\begin{tabular}{|c|c|c|}
\hline Content & Characteristic & Description \\
\hline \multirow{5}{*}{ KM } & $\begin{array}{l}\text { Search and } \\
\text { retrieval }\end{array}$ & $\begin{array}{l}\text { Mainly focused on enhancing the user interface with } \\
\text { sources of information/knowledge, accessibility and } \\
\text { educational agility }\end{array}$ \\
\hline & $\begin{array}{l}\text { Access to } \\
\text { information }\end{array}$ & $\begin{array}{l}\text { Comprises transformation of the data and information } \\
\text { obtained by the end user until it is transferred to the } \\
\text { repository of knowledge }\end{array}$ \\
\hline & User sensitive & $\begin{array}{l}\text { Solution should arrange the information in the manner } \\
\text { most useful to the particular seeker of information }\end{array}$ \\
\hline & Application & $\begin{array}{l}\text { Timely development of organisational and human } \\
\text { knowledge which is connected to intergroup awareness }\end{array}$ \\
\hline & $\begin{array}{l}\text { System learning } \\
\text { agility }\end{array}$ & $\begin{array}{l}\text { Refers to the ease of learning and guidance on how to } \\
\text { use KM }\end{array}$ \\
\hline \multirow{7}{*}{ DT } & $\begin{array}{l}\text { Human and } \\
\text { environmental } \\
\text { interest }\end{array}$ & $\begin{array}{l}\text { Designers need to continuously consider how the } \\
\text { product can meet user needs. Environmental concerns } \\
\text { should be taken into account as key constraints for the } \\
\text { design process at a level of human anxiety }\end{array}$ \\
\hline & Ability to visualise & Designers work creatively (i.e. generate ideas) \\
\hline & $\begin{array}{l}\text { Predilection } \\
\text { towards multiple } \\
\text { roles }\end{array}$ & $\begin{array}{l}\text { Designers should analyse different/multiple solutions } \\
\text { to a problem and keep in mind the big picture of the } \\
\text { problem when focusing on its requirements }\end{array}$ \\
\hline & $\begin{array}{l}\text { Systematic } \\
\text { Prophecy }\end{array}$ & $\begin{array}{l}\text { To build a comprehensive solution, designers view } \\
\text { issues as system problems with the potential for } \\
\text { structural solutions involving various processes and } \\
\text { principles }\end{array}$ \\
\hline & $\begin{array}{l}\text { The desire to use } \\
\text { language as an } \\
\text { instrument }\end{array}$ & $\begin{array}{l}\text { Designers should be able to verbally describe } \\
\text { their creative process of applying creativity where } \\
\text { information is lacking and convey relationships that are } \\
\text { not visually apparent (i.e. description should go hand } \\
\text { in hand with the creative process) }\end{array}$ \\
\hline & $\begin{array}{l}\text { Affinity for } \\
\text { teamwork }\end{array}$ & $\begin{array}{l}\text { Designers must build interpersonal skills that allow } \\
\text { them to interact and work with other people across } \\
\text { disciplines }\end{array}$ \\
\hline & $\begin{array}{l}\text { Avoiding the } \\
\text { necessity of choice }\end{array}$ & $\begin{array}{l}\text { Designers look for viable options before moving on to } \\
\text { making choices or decisions. They try to find ways to } \\
\text { arrive at new configurations. This approach leads to a } \\
\text { solution that prevents decision-taking and blends the } \\
\text { best possible options. }\end{array}$ \\
\hline
\end{tabular}

Source: own research.

\section{Constructions of KM and DT}

During the analysis of literature, Anna Rylander (2009) disclosed specific key characteristics of KM and DT, which are summarised in the table. 
Table 3

Features of KM and DT

\begin{tabular}{lll}
\hline \multicolumn{1}{c}{$\begin{array}{c}\text { Dominant of } \\
\text { constructions }\end{array}$} & \multicolumn{1}{c}{ KM } & DT \\
\hline Knowledge & $\begin{array}{l}\text { Intellectual, model } \\
\text { directed }\end{array}$ & $\begin{array}{l}\text { Hands-on, replication in } \\
\text { action }\end{array}$ \\
\hline Difficult & Tame/Science & Impressive/Undecided \\
\hline Personality & Sensible partying & $\begin{array}{l}\text { Possible rejoicing of } \\
\text { imagination }\end{array}$ \\
\hline $\begin{array}{l}\text { Dominant sense-making } \\
\text { modes }\end{array}$ & Oral communications & $\begin{array}{l}\text { Possible visual contact } \\
\text { with physical objects. }\end{array}$ \\
\hline
\end{tabular}

Source: own research.

\section{Collaborative environment: DT and KM}

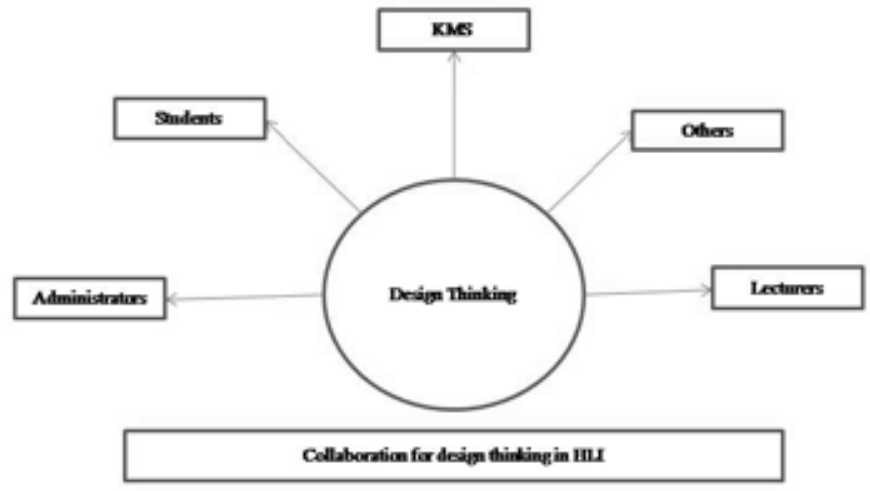

Fig. 1: Collaborative environment: DT and KM.

Source: own research.

Teamwork refers to the team leaders collaborating and working together. Collaboration provides the team with a structure to coordinate their efforts, manage the process and deliver the outstanding outcomes. When each member collaborates on a task or project, he or she should add their energy, expertise, and experience to ensure the project's best outcomes in DT. So, teamwork is important in contrast to the DT project. Cooperation, coordination and teamwork are vital to the existence of every design company and good business behaviour (Mukherjee, 2014), and they play even a greater role in the case of Higher Learning Institution (HLI), where it is necessary to encourage the sharing of information through DT among others such as students, lecturers, supervisors and the broader community. 


\section{PROPOSED DT AND KM MODEL}

Based on the literature review, we propose a KM and DT model (Figure 2) for educational institutions. DT's contributions to KM include focusing on emotion, empathy and fast innovation, and testing even in the presence of difficulty before scaling and trust. Thus, KM programs improve when sufficient empathy is shown to the employee problems and when participatory elements of the design are used to build architecture and processes of KM. Where DT calls for a pragmatic approach to resolving failure, failures are viewed as step-stones towards a final solution. This can benefit organisations educational institutions with information through sharing as a source of learning, not just achievements and best practices but also failures. Most companies and higher educational institutions have a repository of best practices; however, there is not much emphasis on the failed concepts. Most organisations are just focused on the results and the finished goods in their rush toward completion of the project. DT allows generating extra levels of documentation during the path, which may show new insights to subsequent project teams. DT places greater focus on interactions through immersion and engagement and thus provides deeper information about the desires and ambitions of staff, consumers and business partners. Using consumer personals also helps to provide greater holistic insight into the process of academic and company modelling.

DT helps prevent "feature bloat" and often the projects failure by concentrating first on minimum viable products and then complete functionality. In this regard, KM helps to capture best practices for careful creation and production of services. DT and agile methods should be applied right at the specification stage of requirements and not just design and implementation. For example, at the early stages, vendors may dialogue with the business clients and even help them challenge their perception of space and solution path for the problem. Better communication between learning institutions and clients can be achieved and contribute to new avenues of co-creation of knowledge. With its philosophy of "getting out of the building and into the street" and "thinking with your hands," DT brings about better engagement between business, academic institutions and their patrons, particularly in an increasingly digital environment where all kinds of assumptions are made about client expectations and issues. This calls for improved interactive communication formats and the extraction of information during discussion sessions. Through constantly challenging the underlying premises behind problems, DT helps to frame and reframe problem statements more efficiently so that more viable solutions emerge. After all, KM entails not only solving problems in a more intelligent way but also choosing smartly which problems to solve. DT combines top-down and bottom-up approaches to problem-solving, which can help to overcome some of the biases in those KM initiatives that are top-down or led by higher management levels without adequate 360-degree input factoring.

One of the aims of this study is to find the alignment between "DT" and "factory design." There are many times when employees need to adhere stric- 
tly to identified ideology because there are times when available operating hypotheses need to be questioned in the face of emerging contexts. Therefore, success factors definitely play a role - however, the life span is limited, and DT can help develop "next" procedures.

Research work and full absorption throughout the life of skilled professionals must follow the intent to introduce DT viewpoints in KM. Communication with them will produce valuable ideas and theories that need to be implemented and checked regularly before a successful concept can be perfected and adapted for a KM activity.

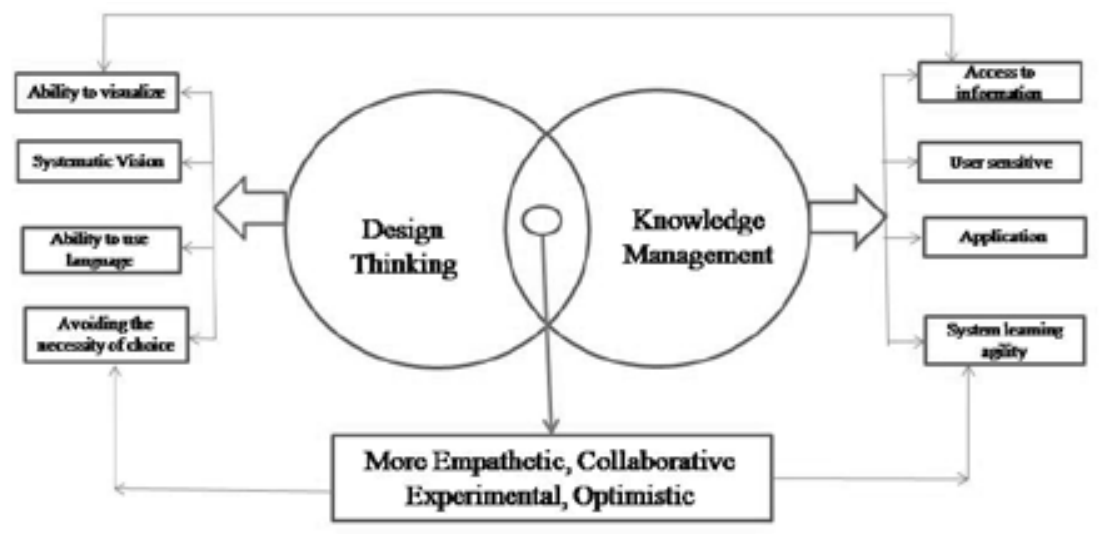

Fig. 2. Proposed DT and KM model.

Source: own research.

The proposed DT and KM model has a total of eight vital aspects. It allows KM to be associated with DT. This model is modest, articulate and relevant to educational institutions. Its concise explanation is given below.

- Ability to visualize: The first stage suggests that the designers possess good knowledge of using visualisation in their work. Using sketches to visualise ideas and communicate thoughts about solutions and propositions is one of their key skills. Sketching is referred to as a way of thinking and creating one's own brainstorms. Through the sketches, new knowledge about the solution arises and is interpreted in the next proposition. The designers use visualisation strategically, but not as effectively as they could.

- Systematic Vision: In the systemic vision, from the beginning of the field and the development of its various disciplines and practices, the definition of framework forms part of design theory and practice. It is often used as tacit knowledge because it takes the place of other similar concepts such as structure, shape, functionality, organisation, etc. (Mukherjee, 2014).

- Ability to use language: DT's ability to use language, the third stage, shows that an industry approach helps think outside of the box, design innovative approaches to our curriculum challenges, and eventually build language curricula that resonate deeply with our teachers and students. 
- Avoiding the necessity of choice: The last point in DT suggests that ambitious designers are looking for their essential characteristics for the competing alternatives and seeking ways to reformulate them into new configurations. When this method works, the outcome is a solution that blends the best of both choices.

- Access to information: However, the fifth level, the KM's access to information, advises that protocols for sharing information are better in strategic information management processes. Access to strategic knowledge is minimal and restricted to a small group of people. Consequently, the method of protecting valuable, sensitive information that cannot be revealed to the public enables information sharing and guarantees the highest degree of protection because unauthorised persons cannot access knowledge bases that contain strategic data.

- User sensitive: Conversely, the user-sensitive level suggests that some of the forum topics might potentially be commercially sensitive, hence it is important to provide password-protected discussion areas accessible upon request from the user.

- Application: The seventh stage shows that transposing application from where it was generated or captured to where it is required and should be used is a key challenge in information implementation. The process feature enables users to be active in specific business processes within their own positions. Through this feature, users have access to KM applications such as information or evidence-based, decision-supporting system applications that enable users and partners to be more receptive to them.

- System learning agility: The final point, system learning agility, demonstrates that the learning/communication process of decision-making unit directly affects the ability to grasp the problem and choices. It controls subsequent behaviours in the form of agility.

The activities of different phases segregate DT and KM in various levels and all events should be given equivalent importance in this model.

\section{CONCLUSIONS AND FUTURE RESEARCH}

Effective execution of KM is influenced by various factors. These factors are both organizational and human; furthermore, it is indicated that inclination of the employees to contribute in KM procedure leads to a fruitful application (Al-Mahruqi, Bouazza, \& Al-Suqri, 2019). Converting knowledge from one type to another is crucial in creating new knowledge. $\mathrm{KM}$ has been viewed as creating new products, services and processes and deriving values from knowledge, particularly in tying knowledge to actions (Deloitte, 2020). Students should be conscious of the possibility and reflect on their process in order to strategically create new design knowledge (Thoring \& Mueller, 2011). This paper is an attempt at providing a solution space for KM in DT approach by building a framework and a model for classifying harmonious KM and DT research efforts 
in the overall context. Based on the present study, it is possible to observe the practicality of this model and the essentiality of knowledge sharing in each KM framework. Future work should be parallel with our findings for other higher academic institutions and with DT projects outside the educational context. In addition, more advanced studies should similarly be performed on how lecturers can prepare the appropriate expertise preceding the executing of DT in their educational institutions (Lor, 2017). For successfully applying DT and KM in higher learning institutions course design, strategy institutional support, faculty resource sharing and improvement is necessary. Future work should compare our findings with other educational organisations and with the DT process in KM context. Further research on the topic might also involve a comparison of our suggested model with other DT processes, as well as a comparison with the KM. Developing such an intuition and to extract tacit knowledge might be one of the challenges of DT. Further research on that topic is planned. We see the main contribution of this article in the stimulation of reflecting the DT process in KM.

\section{REFERENCES}

[1] Abdullah, R., Selamat, M. H., Sahibudin, S., \& Alias, R. A. (2005). A framework for knowledge management system implementation in collaborative environment for higher learning institution. Journal of Knowledge Management Practice, 6(1), 1-8.

[2] Agarwal, N. K., Poo. D. C., \& Goh, J. M. (2005). Managing quality of information retrieval for effective knowledge management. In: Proceedings of the 3rd World Conference for Software Quality (3WCSQ), 205-214.

[3] Alavi, M., \& Leidner, D. E. (2001). Knowledge management and knowledge management systems: Conceptual foundations and research issues. MIS Quarterly, 1(10), 107-135.

[4] Alexander, C. (1964). Notes on the synthesis of form. Boston: Harvard University Press.

[5] Al-Mahruqi, H. N., Bouazza, A., \& Al-Suqri, M. N. (2019). Readiness of public and private sector organizations for knowledge management: A literature review. Journal of Arts $\mathcal{E}$ Social Sciences, 10(2), 5-19.

[6] Beckman, S. L., \& Barry, M. (2007). Innovation as a learning process: Embedding design thinking. California Management Review, 50(1), 25-56.

[7] Beckman, T. (1998). Knowledge management seminar notes. ITESM, Monterrey, Mexico, June 24-26.

[8] Bhatt, G. D. (2001). Knowledge management in organizations: examining the interaction between technologies, techniques, and people. Journal of Knowledge Management, 5(1), 68-75.

[9] Boisot, M. (1987). Information and Organizations: The Manager as Anthropologist. London: Fontana Press.

[10] Bouthillier, F., \& Shearer, K. (2002). Understanding knowledge management and information management: The need for an empirical perspective. Information Research, 8(1), 8-1.

[11] Buchanan, R. (1992). Wicked problems in design thinking. Design issues, 8(2), 5-21.

[12] Chujfi, S., \& Meinel, C. (2020). Matching cognitively sympathetic individual styles to develop collective intelligence in digital communities. AI \& Soc, 35, 5-15. Retrieved July 29, 2020, from https://doi-org.ezlib.iium.edu.my/10.1007/s00146-017-0780-x.

[13] Cucovic, A., \& Cucovic, O. (2014). The importance of knowledge management in contemporary management. Viti, 3, 26-34.

[14] Dorton, S., Tupper, S., \& Maryeski, L. (2017). Going digital: Consequences of increasing resolution of a war gaming tool for knowledge elicitation. Proceedings of the Human Factors and Ergonomics Society Annual Meeting, 61(1), 2037-2041. doi: 10.1177/1541931213601988. 
[15] Davenport, T. H., \& Prusak, L. (1998). Working Knowledge: How Organizations Manage What They Know. Boston: Harvard Business School Press.

[16] Deloitte Insights. (2020). Deloitte Global Human Capital Trends Survey 2020. London: Deloitte Insights.

[17] Elsbach, K. D. (2018). Design thinking and organizational culture: A review and framework for future research. Journal of Management, 20(10), 1- 33.

[18] Feather, J., \& Sturges, P. (2003). International Encyclopedia of Information and Library Science. (2 ed.) London: Routledge.

[19] Frid, R. (2003). A common KM framework for the Government of Canada: Frid framework for enterprise knowledge management. Canadian Institute of Knowledge Management, Ontario: Canadian Institute of Knowledge Management.

[20] Grayson, C. J., \& O'Dell, C. (1998). Mining your hidden resources. Across the Board, 35(4), 23-28

[21] Gregory, S. A. (1966). The Design Method. London: Butterworth.

[22] Hassi, L., \& Laakso, M. (2011, October). Conceptions of Design Thinking in the design and management discourses. In Proceedings of IASDR2011, the 4th world conference on design research, Delft (pp. 1-10).

[23] Jain, P. (2013). Knowledge management in academic libraries and information centres: A case of university libraries. Journal of Information and Knowledge Management, 12(4), 1-13.

[24] Johansson-Sköldberg, U., Woodilla, J., \& Çetinkaya, M. (2013). Design thinking: past, present and possible futures. Creativity and Innovation Management, 22(2), 121-146.

[25] Karadsheh, L., Mansour, E. M., Alhawari, S., Azar, G., \& Naser, E-B. (2009). A theoretical framework for knowledge management process: towards improving knowledge performance. Communications of the IBIMA, 7, 67-79.

[26] Kimbell, L., \& Street, P. E. (2009, September). Beyond design thinking: Design-as-practice and designs-in-practice. In CRESC Conference, Manchester (pp. 1-15).

[27] Kolb, D. A. (2014). Experiential Learning: Experience as the Source of Learning and Development. London: FT Press.

[28] Lai, H., \& Chu, T. H. (2000, January). Knowledge management: A review of theoretical frameworks and industrial cases. In Proceedings of the 33rd Annual Hawaii International Conference on System Sciences (pp. 10-pp). IEEE.

[29] Lank, E. (1997). Leveraging invisible assets: the human factor. Long Range Planning, 30(3) 406-412.

[30] Leuzinger, R., Lee, G. K. \& Korber, I. (2013). Keeping up With Design Thinking. Association of College \& Research Libraries (ACRL). Retrieved July 29, 2020, from www.ala.org/acrl/ publications/keeping_up_with/design.

[31] Liebowitz, J. (1999). Building Organizational Intelligence: A Knowledge Management Primer. Boca Raton: CRC Press.

[32] Lor, R. R. (2017). Design thinking in education: A critical review of literature, Conference Proceedings, Bangkok.

[33] Luka, I. (2014). Design thinking in Pedagogy. Journal of Education Culture and Society, 2, 63-74.

[34] Marquardt, M. J. (1996). Building the Learning Organization: A Systems Approach to Quantum Improvement and Global Success. New York: McGraw-Hill.

[35] McAdam, R., \& McCreedy, S. (1999). A critical review of knowledge management models. The Learning Organization, 6(3), 91-101.

[36] Mostofa, S. M., \& Sultana, N. (2019). Present scenario of knowledge management effectuation in the national library of Bangladesh: A study. Journal of Multidiscip. Science, 1(2), 1-8.

[37] Mukherjee, D. (2014). Factors of management education in India as perceived by learners and providers: An empirical study. Vision, 18(2), 73-80.

[38] Parikh, M. (2001). Knowledge Management Framework for High-Tech Research and Development. Engineering Management Journal, 13(3), 27-34.

[39] Razzouk, R., \& Shute, V. J. (2012). What is design thinking and why is it important? Review of Educational Research, 82(3), 330-348.

[40] Rittel, H. (1972). On the planning crisis: Systems analysis of the 'first and second generations'. Bedriftskonomen, 8, 390-396.

[41] Rowley, J. (2001). Knowledge management in pursuit of learning: the learning with knowledge cycle. Journal of Information Science, 27(4), 227-236. 
[42] Rubenstein-Montano, B., Liebowitz, J., Buchwalter, J. McCaw, D., Newman, B., \& Rebeck K., (2001). A systems thinking framework for knowledge management. Decision Support Systems, 31, 5-16.

[43] Rylander, A. (2009). Design thinking as knowledge work: Epistemological foundations and practical implications. Journal of Design Management, 4(1), 7-19.

[44] Shute, V. J., \& Becker, B. J. (2010). Innovative Assessment for the 21st Century. New York, NY: Springer-Verlag.

[45] Simon, H. A. (1969). The Sciences of the Artificial. Cambridge, MA: MIT Press.

[46] Stankosky, M., \& Baldanza, C. R. (2001). A Systems Approach to Engineering a KM System. Unpublished manuscript.

[47] Stumpf, S. C., \& McDonnell, J. T. (2002). Talking about team framing: Using argumentation to analyse and support experiential learning in early design episodes. Design Studies, 23, 5-23.

[48] Supyuenyong, V., \& Islam, N. (2006). Knowledge management architecture: Building blocks and their relationships. Technology Management for the Global Future, 3, 1210-1219.

[49] Thoring, K., \& Müller, R. (2011, October). Creating knowledge in design thinking. In The relationship of process steps and knowledge types. Paper presented at the Proceedings of IASDR2011, the 4th World Conference on Design Research, Delft (pp. 1-9).

[50] Tyndale, P. (2000). The organisational knowledge development life cycle. Proceedings of the European Conference on Knowledge Management.

[51] Walch, M., Morita, T., Karagiannis, D., \& Yamaguchi, T. (2019). A knowledge-based conceptual modelling approach to bridge design thinking and intelligent environments. In: C. Douligeris, D. Karagiannis \& D. Apostolou (Eds.), Knowledge Science, Engineering and Management. KSEM. Lecture Notes in Computer Science (pp. 524-536). Greece: Springer.

[52] Wang, S., \& Wang, H. (2008). A design thinking approach to teaching knowledge management. Journal of Information Systems Education, 19(2), 137-140.

[53] Welsh, M. A., \& Dehler, G. E. (2012). Combining critical reflection and design thinking to develop integrative learners. Journal of Management Education, 20(10), 1-32.

[54] Young, R. (2008). Knowledge associates international KM definition. Retrieved July 29, 2020, from http://www.knowledge-managementonline.com/knowledge-associates-international-km-definition.html.

[55] Zahedi, M., Poldma, T., Baha, E., \& Haats, T. (2012). Design thinking and aesthetic meaning-making: Interlaced means to engage in collaborative knowledge-building. In DS 71: Proceedings of NordDesign 2012, the 9th NordDesign conference, Aarlborg University, Denmark. 22-24.08.2012. 